\title{
Regional Spatial Disparities in Bulgarian Tourism in Pandemic Context
}

\author{
Desislava Varadzhakova \\ National Institute of Geophysics, Geodesy and Geography \\ Bulgarian Academy of Sciences \\ Sofia, Bulgaria \\ dvaradzhakova@gmail.com
}

\begin{abstract}
Tourism is an important sector of the Bulgarian economy. Several intra-regional differences characterize tourism in Bulgaria. The physical-geographical specifics of the country determine these distinctions. The development of a pandemic and travel restrictions around the world are leading to the collapse of the tourism industry. The purpose of this article is to analyze the impact of the pandemic on Bulgarian tourism, taking into account their severity in various statistical regions of the country at the NUTS 2 level. To achieve this goal, a literature review and analysis of the main characteristics of Bulgarian tourism are carried out. Analyzes the official statistics of tourism in the country before and during the pandemic by region. There is also a qualitative and quantitative assessment of these accommodation institutions, arrival (foreigners) in housing, arrival of Bulgarians in housing, income from nights spent. The increase in the number of infected in the country in early autumn leads to restrictive measures and unpredictable consequences for the upcoming winter tourist season. The first year of the coronavirus has been found to severely damage tourism and consumer perceptions of safe travel. Conclusions were formulated on the socio-economic consequences of the spread of the coronavirus pandemic for the regional markets of Bulgaria.
\end{abstract}

\section{Keywords-COVID-19, tourism, regions, NUTS 2.}

\section{INTRODUCTION}

The specific characteristics of the tourist activities and the tourist product determine their great connection with the possibility for free movement of people. This is the reason why such significant events as political and military conflicts, economic crises, epidemics or pandemics and other regional or global adverse events can have a serious negative impact on the tourism industry.

The rapid spread of COVID-19 in just a few months in early 2020 led to an almost complete lockdown of the world and a halt in travel. One of the most affected industries in this pandemic is tourism. It has an extremely perceivable negative effect, especially in countries where this sector has a significant share in their economies. In European Union, tourism industry contributes about $10 \%$ of EU GDP, $12 \%$ of the employment and 23 million direct and indirect jobs are generated in this business. According to the European Commission, Bulgaria is among the top ten Member States which are very dependent on tourism. The sector contributes around $12 \%$ to the country's GDP annually. [1]
The last five years we see a steady increase in tourist arrivals in Bulgaria, but in 2020 all indicators related to tourism activities, reported by the National Statistical Institute of the country, decline. To reduce the negative consequences of the growing pandemic, Bulgaria, as a member of the European Union, is taking a number of socioeconomic measures that are in line with the legal framework of the EU and the country. The main goal of the measures taken is to support the tourism industry, to preserve jobs in this sector and to provide sufficient funds for consumers to travel.

Several intra-regional differences characterize tourism in Bulgaria. The physical-geographical specifics of the country determine these distinctions. The climate in most of the country is temperate continental with four distinct seasons spring, summer, autumn and winter. To the east, Bulgaria borders the Black Sea, with a coastline of $378 \mathrm{~km}$, of which $200 \mathrm{~km}$ are beaches covered by sand. The beaches and the sea offer favorable conditions for practicing various types of water sports (surfing, water skiing, diving, underwater archeology) and fishing. Bulgarian Black Sea resorts offer a variety of accommodation options - from luxury 4-5-star hotels to small romantic family hotels that meet world standards. They are suitable for family vacations as well as for individuals and entertainment. One third of the country's territory is covered by nearly 40 different mountains, which are diverse in area, height, relief and flora and fauna. They are beautiful and accessible both in summer and in winter and offer excellent conditions for sports, recreation and walking. [2]

In recent years, low-cost airlines fly to the capital of Bulgaria, Sofia, connecting it with almost all European countries. Relatively low prices of food and beverages, competitive hotel prices, variety of cultural and historical sites are a prerequisite for the development of weekend tourism. Taking into account the importance of the physical and geographical factors on the spatial development of the different types of tourism in the country, we can distinguish areas where summer sea tourism, winter ski tourism, cultural, heritage, SPA and weekend tourism are developed. The purpose of this article is to analyze the impacts of the pandemic on Bulgarian tourism, taking into account their severity in different statistical regions of the country at NUTS 2 level. 
It is still difficult to determine the time and exact location of the pandemic occurrence. The first officially announced cases are from the last days of 2019 from the city of Wuhan in China. In Europe, the coronavirus is thought to appear simultaneously in Germany and France around 1 February 2020. In France, one of the French citizens traveling to the city of Wuhan is believed to be carrying the infection. In Germany, there is also an infected employee of a Bavarian company who has been negotiating with Chinese partners again in Wuhan. [3]

The first proven case of COVID-19 in Bulgaria dates from March 8, 2020. On March 13, 2020, after 16 confirmed cases in one day, the government declared a state of emergency throughout the country for a period of one month, which was extended until May 13, 2020. All schools, malls, bars, discos, cinemas, restaurants and gyms are closed. Due to cases of sick tourists with COVID-19 on March 17, 2020 for a period of 14 days the winter resort of Bansko was closed, including all hotels except those in which there are foreign tourists that have not been left. On March 20, 2020, a ban on visiting parks, playgrounds and outdoor and indoor sports facilities come into force. The government forbids the citizens of the regional centers to leave the cities without a valid reason as going to work in another place, health reasons or when the persons return to the places where they are registered at a permanent or current address. The blockade does not apply to vehicles that carry medicines and food, special purpose vehicles and others. On April 6, 2020, there is a ban to entry into the territory of the Republic of Bulgaria through the borders by air, sea, rail and road transport for citizens from 13 EU member states and all non-EU countries. The ban is valid until May 14, 2020. On April 16, flights from Great Britain are suspended. On April 17, 2020, a strict regime of entry and exit from Sofia is introduced, and on April 21 the strict measures are eased for the capital and those that apply to all regional cities remain. The access to the beach is prohibited in the largest Black Sea city - Varna. All shops that are not affected by the announced bans also close or reduces their working time. Many business switches to part-time work or home office work.

From 14 May to 14 June, a state of emergency is replaced by state of epidemic situation. Firstly, it is extended to 30 June, then to 15 July, which lasted until the end of September. During this period the restaurants are open. Many requirements for their work are imposed. For example, the staff has to wear masks and/or helmets, the tables have to be put in larger distance, to admit up to 6 people at one table, to clean with disinfectant tables and chairs after each client. Shopping centers, sports halls, theaters are open, but there are restrictions related to a distance of $1.5 \mathrm{~m}$ between visitors, wearing masks, up to $30 \%$ occupancy and disinfection at the entrance of the sites.

Bulgarian tourism is characterized by a distinct seasonality: winter active tourist season (from December to March) and summer active tourist season (from mid-June to mid-September). A retrospective of the virus spread shows that in fact during the entire active summer tourist season in Bulgaria there are different restrictions for incoming tourists, as well as requirements for Bulgarian citizens. These requirements are related to wearing masks and helmets, compliance with the distance between people and limiting the contacts, disinfecting surfaces and washing hands often, or the so called 3D measures (distance, disinfection, discipline). There are also additional sanitary requirements for accommodation establishments and restaurants, as it is in the post COVID-19 era safety, sanitation and hygiene are very important for tourists. [4]

\section{LITERATURE REVIEW}

The negative economic impact of the pandemic on the tourism business is a result of many factors such as travel restrictions, flight cancellations, restaurant closures, fear and uncertainty of the new virus, lack of an established treatment protocol and vaccine, inconsistent and even conflicting information about the ways the virus spreads, etc. As the number of infected people around the world grows, many researches, in all areas of knowledge in 2020, focuses on the problems caused by the coronavirus. As the pandemic is growing, the publications that appear in scientific journals, related to various aspects of the impact of COVID-19 on tourism, focus mainly on the post-crisis period. One of the main directions in the research aims at researching the attitudes of tourists in the post-pandemic period. [4, 5, 6, 7, $8,9]$. A number of authors also consider the effect of the pandemic on the tourism industry through the point of view of the companies providing and offering tourism services. $[10,11,12]$ The third group of researchers considers the reactions of travelers during the pandemic $[13,14]$. A limited number of empirical studies focus on economic impacts of the pandemic at regional level.

\section{METHODS}

The current analysis of the effects of the COVID-19 pandemic on Bulgarian tourism is based on statistical data at NUTS 2 level.The NUTS classification (Nomenclature of territorial units for statistics) is a hierarchical system for dividing up the economic territory of the EU and the UK for the purpose of:

- The collection, development and harmonization of European regional statistics;

- $\quad$ Socio-economic analyses of the regions /NUTS 1: major socio-economic regions; NUTS 2: basic regions for the application of regional policies; and NUTS 3: small regions for specific diagnoses/;

\section{- $\quad$ Framing of EU regional policies. [15]}

At NUTS 2 level, Bulgaria is divided into six regions (Northeastern - NE, North Central - NC, Northwestern - NW, Southwestern - SW, South Central - SC and Southeastern SE regions). According to the Regional Development Act of Republic of Bulgaria, they do not represent administrativeterritorial units, but serve statistical purposes. As the statistical regions are used for economic analyzes, this article focuses on the data gathered for the above mentioned six regions, covering the entire territory of Bulgaria. 


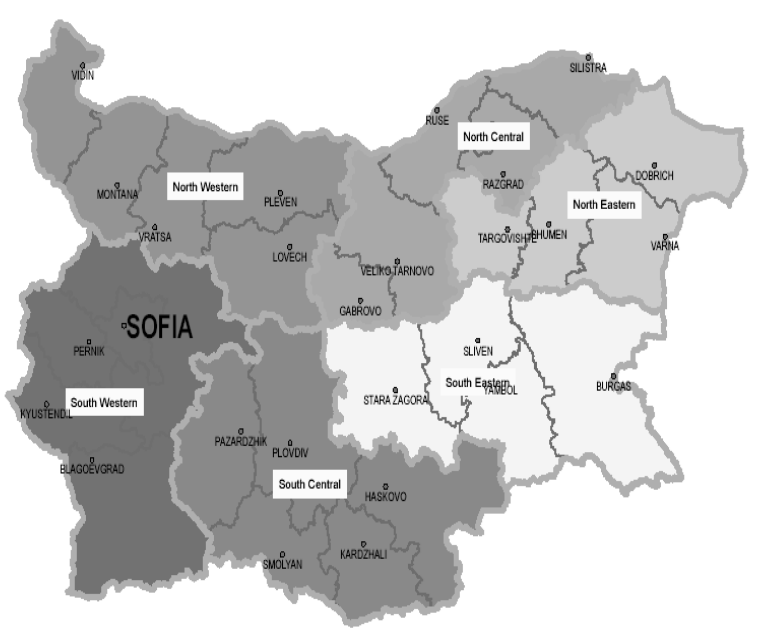

Fig. 1. Current NUTS 2 regions of Bulgaria

Source: Ministry of Regional Development and Public Works of Republic of Bulgaria

The study period /March - September 2020/ covers the months when coronavirus infection cases are registered in the country. The final date of the analyzed period - September 2020 is determined by the available officially published statistics on the main tourist indicators. For the purposes of the analysis, the data from 2020 is compared with those from the same period of the previous year. Statistical, analytical and descriptive methods are used.

\section{REGIONAL ANALYSIS BY MAIN TOURIST INDICATORS}

To measure the effects of the coronavirus pandemic on the tourism industry in Bulgaria, indicators such as number of operating accommodation establishments, arrivals of Bulgarians and foreigners in the accommodation facilities, revenues of accommodation places are used. The analysis is based on the official data of the National Statistical Institute of the Republic of Bulgaria.

\subsection{Accommodation establishments}

The accommodation establishments included in the present analysis have a capacity of at least 10 beds, according to the methodology of the National Statistical Institute of the Republic of Bulgaria. As a result of the pandemic, there is a decrease of $29 \%$ in the analyzed period of 2020 compared to 2019. The decrease in the number of operating accommodation establishments does not vary significantly by regions. It is between $21 \%$ and $32 \%$. There is a slight increase in the number of operating accommodation establishments in the period June-September, which is due to the abolition of the lockdown in May 2020 and the traditional vacation period in the country.
Avarage monthly number of operating accommodation establishments

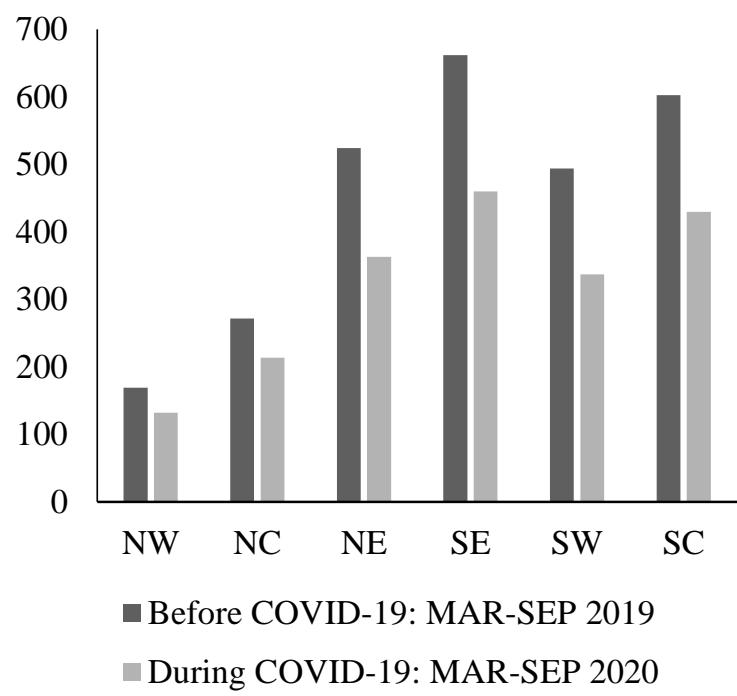

Fig. 2. Average monthly number of operating accommodation establishments by regions

The regions with the highest average monthly number of operating accommodation establishments, before the pandemic, are respectively Southeastern region /662/, South Central region /603/, Northeastern region /524/ and Southwestern region /494/. They mark a higher decrease in the average monthly number of operating accommodation establishments - between $29 \%$ and $32 \%$. The three provinces that have access to the Black Sea form part of the territory of the Southeastern and Northeastern regions. For this reason, a significant part of the accommodation facilities located there traditionally work only during the summer season. The seasonality is higher in the accommodation establishments in the Southeastern region, where the number of operating hotels in the summer is 5 times higher than in the winter. In the Northeastern region the seasonality is less differentiated and during the active summer season there are 3 times more operating accommodation establishments. After the spread of the coronavirus pandemic in Bulgariaq during the summer season the decrease in the number of working accommodation facilities in the Southeastern region is between $18 \%$ and $42 \%$, and in the Northeastern region is slightly lower - between $16 \%$ and $37 \%$. In both regions, the largest decline is reported in the first month after the lockdown - the month of June. From July 2020 relatively stable levels of decline are established. This is due to the decision of many hoteliers to open, albeit later in the active summer season.

There is no seasonality in the demand of tourist services in the South Central and Southwestern regions. This is the reason why the average monthly number of operating hotels is relatively constant. However, the decrease in the average monthly number of accommodation places in the study period is among the higher ones, respectively $29 \%$ for South Central region and $32 \%$ for Southwestern region. As a result of the pandemic and the ban on gathering of many people indoors, the biggest business events were severely restricted. This fact also reflects on the occupancy of the accommodation establishments and led to the closure of many sites, especially in large cities. The two largest cities in Bulgaria are located 
on the territory of the Southwestern and the South Central regions, respectively the capital Sofia /in Southwestern region/ and the second largest city in the country - Plovdiv /in South Central region/. These two cities are also some of the main emitting markets for tourists, but they are less attractive for visits during the summer months.

The Northwestern region is the least developed in terms of the built tourist superstructure. It has the smallest number of establishments with more than 10 beds capacity compared to the other regions. In the Northwestern and in the North Central regions, the characteristics of the tourist resources are not a prerequisite for strong seasonality, therefore the fluctuations in the number of operating accommodation establishments within the year are not large. The number of working accommodation facilities remains relatively constant throughout the year. The consequences of the pandemic on this indicator in both regions is the lowest $/ 21 \%$ $-22 \% /$ compared to the rest country's regions.

\subsection{Arrivals (of foreigners) in accommodation establishments}

The average monthly number of arrivals of foreigners in the accommodation establishments in Bulgaria for the analyzed period - March-September 2020 decreased by $77 \%$ compared to the same period of 2019. Apart from the growing pandemic, this decline is due to the travel restrictions, the flight cancellations, the lack of national standards for hygiene and health safety in accommodation facilities, the increasing number of infected after the abolition of the lockdown in mid-May 2020.

Average monthly number of foreigners' arrivals in accomodation establishments (in thousands)

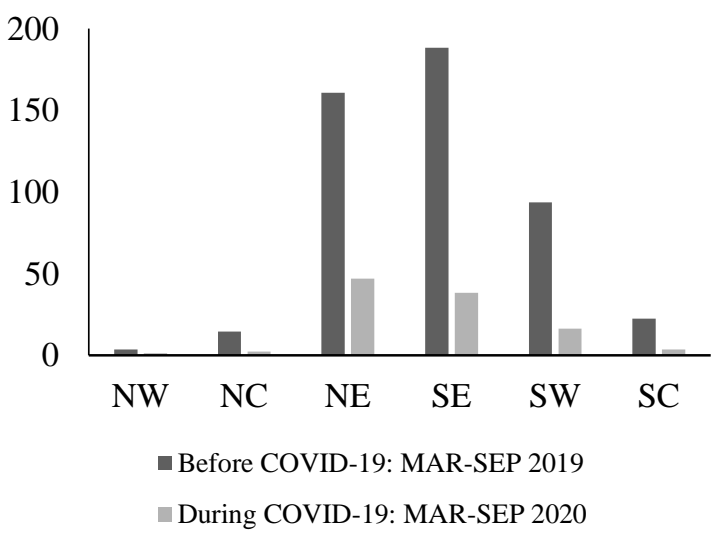

Fig. 3. Average monthly number of foreigners' arrivals in accommodation establishments

The average monthly arrivals by foreigners in accommodation establishments records the smallest decrease in North West region /62\%/. Apart from the general reasons for the decrease in visits of foreign citizens, the weaker decline in the region is mainly due to the local, regional and national importance of the tourist resources located on their territory and the traditionally weaker dependence on international tourism.

The Northeastern region recorded a decline of $71 \%$, but together with Southeastern $/ 80 \% /$ and Southwestern region $182 \% /$ recorded the largest decline in the average monthly number of foreigners in absolute terms. The Northeastern and the Southeastern regions are highly dependent on the visit of foreigners in the summer months, as two provinces in
Northeastern region /Varna and Dobrich/ and one province in Southeastern region /Burgas/ include the Black Sea shore. The Black Sea is the main tourist resource for practicing summer sea tourism and is a major motive for increasing incoming tourism every year in the period June-September. This period form part of the scope of the analyzed period. The Black Sea coast and the climate along it determine the seasonality of tourist visits by foreigners in Northeastern and Southeastern regions. Except the summer sea tourism in the Northeastern region, business tourism is also developed. This is the reason why the dependence on seasonality is slightly lower than in the Southeastern region. After the abolition of the lockdown, most charter flights to Varna Airport and Bourgas Airport /respectively in Northeastern region and Southeastern region/, serving the Black Sea resorts, are canceled. Incoming trips are reduced to urgent business trips with regular flights. The variety of destinations /over 10 countries/ connected with Varna, through year-round scheduled flights, shows the greater demand for Northeastern region as a tourist destination, compared to Southeastern region. The Southeastern region is connected through Bourgas Airport, with year-round scheduled flights, only with London and Moscow.

According to the average monthly number of arrivals of foreigners who spent nights at accommodation establishments, following the Northeastern and the Southeastern regions, is the Southwestern region. The regional city center is the capital of Bulgaria - Sofia. Sofia is connected by regular and low-cost flights with most of the European capitals and major cities on the continent. The expansion of low-cost flights from Sofia Airport makes the capital an attractive destination for city breaks and the number of foreign tourists in the city increase. Due to the concentration of administrative and business organizations in the capital, it is also a major destination for business tourism. The region also includes the Rila Monastery, which is the largest in the country and is one of the nine sites in Bulgaria included in the UNESCO world heritage list. The ski resorts of Borovets and Bansko are also located in the Southwestern region. Borovets offers a variety of activities both in winter and summer. However, the object of visits by foreign tourists is mainly during the winter season. Bansko is the biggest ski center on the Balkans. Bansko is a destination visited all year round due to its cultural calendar, the mineral springs near the town, the opportunities for various activities in the summer season in the region/such as kayaking, mountain hiking tours, mountain biking, etc/. Despite the variety of activities during the summer season, the destination is visited by foreigners mainly during the winter season - DecemberMarch.

The North Central region and the South Central region mark the largest decrease in the average monthly arrivals of foreigners in percentages, $83 \%$ and $84 \%$, respectively. Despite the large decline in the average monthly number of overnight stays of foreigners in the North Central region, in numbers $/ 2420$ / this region ranks second to last, only before the Northwestern region. This is due to the fact that there are no large resorts of international importance in the North Central region. Foreigners visiting this region are interested in the spiritual capital of Bulgaria - Veliko Tarnovo. It is part of the classic tours of Bulgaria. Another city attractive for the foreign tourists is the city of Ruse. It is visited by tourists arriving by river cruises on the Danube River and tourists from Romania.

South Central region ranks fourth in average monthly number of foreigners arrivals in accommodation establishments respectively 22611 in the analyzed period of 
2019 and only 3535 in 2020 . Within the South Central region is located the second largest city in Bulgaria - Plovdiv. It is an attractive destination for cultural heritage and for business tourism. The tourist mountain resort Pamporovo also has an impact on the tourist indicators. The main period for visiting the resort is in winter, although there are a number of attractive activities in summer.

\subsection{Arrivals of Bulgarians in accommodation establishments}

The COVID-19 epidemic and the restrictions imposed to reduce the spread of the infection are also affecting domestic tourism. The average monthly number of arrivals of Bulgarians in accommodation establishments in the analyzed period of 2020 decreases by $33 \%$ compared to the same period in 2019. By regions the decrease is between 7 and 52\% and it is much lower than the results of the same indicator for foreign citizens /between $62 \%$ and $84 \%$ /.

Average monthly number of Bulgarians' arrivals in accomodation establishments

(in thousands)

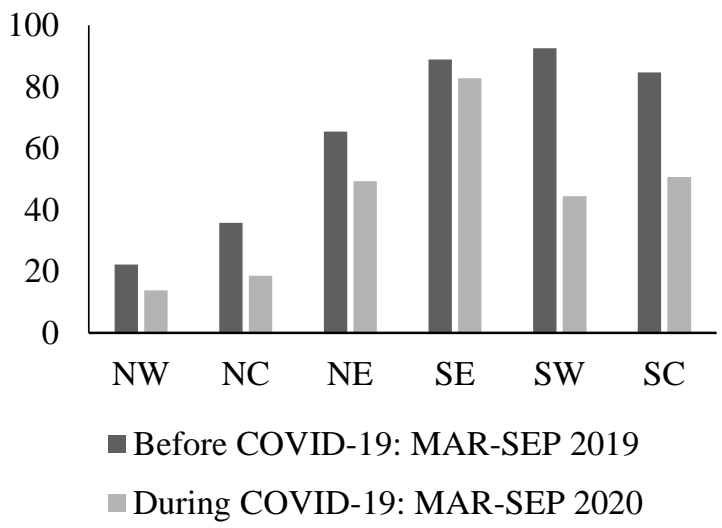

Fig. 4. Average monthly number of Bulgarians' arrivals in accommodation establishments

The decline by region differs significantly from that of the same indicator for foreign nationals. A study conducted in the first month of lockdown in Bulgaria [3] shows that $61.4 \%$ of respondents plan to spend their summer holidays in Bulgaria. $50.9 \%$ plan to visit the Black Sea coast. The National Statistical Institute' data prove that these intentions are realized. The least affected is the Southeastern region, which recorded a decline of only $7 \%$. Southeastern region has the largest accommodation facilities in the country, which is concentrated mainly in the Burgas province. Some of the most visited resorts on the Black Sea coast are located there. According to National Statistical Institute data, even in July and September 2020, more Bulgarians spent nights in the Southeastern region than the same months of 2019. This fact explains the slight decline in the average monthly visits to the region at the analyzed period. Northeastern region also marks a significantly lower decline $/ 25 \% /$ in the average monthly number of Bulgarians spending the night in accommodation establishments, compared to other regions of the country. In July and August 2020 the flow of Bulgarian tourists to the northern Black Sea resorts is higher than the same months of 2019. Seasonality is typical for these regions due to the specifics of the tourist resources located there. It is the stronger domestic tourism during the summer months that reduces the decline in the average monthly number of Bulgarians who spend nights in Southeastern and Northeastern regions. Among the main reasons for the relatively good performance of the domestic tourism in these regions are: the fear of coronavirus infection when traveling by public transport, the cancellation of many charter flights on planned organized tours abroad, the introduction of a mandatory negative PCR test for entry into Greece, which is a traditionally visited summer destination by Bulgarians, the high number of infected people in Italy and Spain, which are desirable tourist destinations by Bulgarian tourists, as well.

The results show that domestic tourism after lockdown is not compensated equally in all regions. The main tourist flow after the abolition of travel restrictions and the closure of regional cities is to the Black Sea coast, but domestic urban tourism or mountain tourism during the summer months show little interest. The highest decrease is in the average monthly number of Bulgarians spending the night in Southwestern region $152 \%$. Sofia, as it is the center of the region and the largest city in the country, is an emitting tourist destination. Despite the variety of activities offered by the mountain resorts of Bansko and Borovets, the tourist flow of Bulgarians is not sufficient to significantly compensate the decline that is result of the lockdown period.

North Central region, South Central region and Northwestern region mark a decrease in the average monthly number of Bulgarian citizens who spent the night in accommodation establishments, respectively $48 \%, 40 \%$ and $38 \%$. These regions are characterized by lower seasonality in tourist visits. In the Northwestern region in the months of July and August 2020 there is an increase in the number of Bulgarians who spent the night in accommodation properties. In North Central and in South Central regions only in one of the summer months there is an increase in the average number of overnight stays of Bulgarians in 2020. The lack of large resorts, attractive in the summer months, leads to inability to compensate the reduced number of arrivals of Bulgarian citizens during lockdown and the first months after that.

\subsection{Revenues from nights spent}

Accommodation establishments mark a drop in average monthly revenue from overnight stays of $64 \%$. Many of them try to attract more tourists with lower prices than usual for their category and services offered.

Average monthly revenues from nights spent (MM BGN)

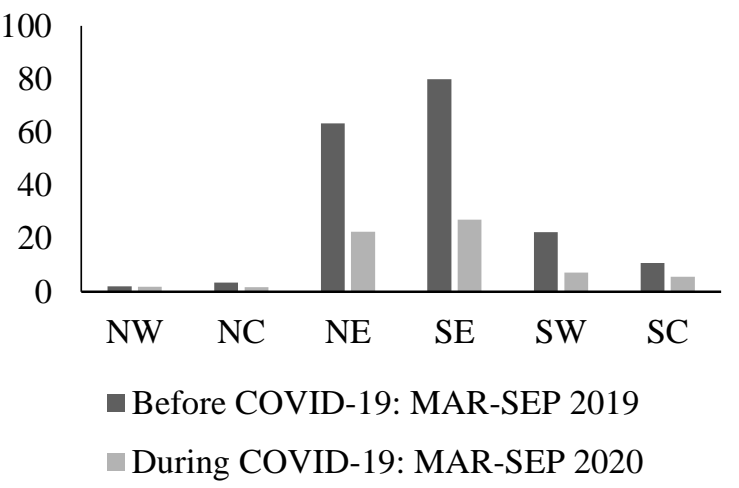

Fig. 5. Average monthly revenues from nights spent

The most serious decline in the average monthly revenue from overnight stays is noted in the Southwestern, 
Southeastern and Northeastern regions, respectively $68 \%$, $66 \%$ and $64 \%$. This decline is due to the high dependence of these regions on inbound tourism, which in 2020 marked a significant decrease. According to the Sofia Investment Agency before the pandemic, the trend is about $2 / 3$ of the nights in Sofia to be realized by foreigners. [16] The number of passengers served at Sofia Airport between March and September 2020 has decreased by an average of $70 \%$, compared to the same period of 2019. [17]

Many seasonal hotels on the Black Sea coast did not open during the summer season of 2020 or opened later than usual. This is the reason why the capacity of the operating accommodation establishments is very limited. Given the reduced tourist flow of foreigners, the sharp decline in revenues from overnight stays in Northeastern and Southeastern regions is expected.

Revenues from overnight stays in the central part of the country /North Central region and South Central region/ have decreased by $50 \%$. This percentage is relatively smaller compared to the decline in the three most affected regions (Southeastern, Southwestern and Northeastern region) because in the central part of the country the recreational tourism is less developed. There are tourist resources for practicing cultural, heritage and business tourism. As the analyzed period covers the active summer tourist season, therefore, leisure trips have a relatively greater weight on the decline in revenues. In the central regions, the decrease can be explained by the restrictions imposed on cultural and business events (occupancy up to $30 \%$ of the halls), a distance of at least 1.5 meters between visitors to cultural and historical sites, self-restraint when traveling by public intercity transport, etc. In this part of the country many accommodation establishments are closed.

In the Northwestern region, the decrease in the revenue from overnight stays is insignificant - 3\%, despite the fact that there is a decline in the number of accommodation establishments by about $20 \%$, of arrivals of foreigners about $60 \%$, and of Bulgarians - about $40 \%$. This fact can be explained by the choice of the tourists to spend nights in a higher category accommodation properties with a correspondingly higher price per night. This is due to the higher sanitary, hygienic and disinfection requirements of the customers.

\section{CONCLUSION}

The negative effects of the coronavirus pandemic on Bulgarian tourism are indisputable. Numerous restrictions on travel in and outside Bulgaria, the complete and subsequent partial closure of food and entertainment establishments, as well as the lack of uniform hygiene and health standards valid for all accommodation facilities in the country, have contributed to the decline in consumers confidence in their safe stay. The increase in the number of infected after the abolition of the lockdown also lead to the cancellation of charter flights from major emitting markets for the summer season 2020. These factors lead to the bankruptcy of many restaurants and entertainment establishments, as well as the decision of hoteliers not to work during the active summer season on the Black Sea coast. After the lockdown, tourists are interested in smaller accommodation properties, where fewer people congregate and the risk of coronavirus infection is limited. The growing number of infected people in the country in the beginning of the autumn leads to new restrictive measures and unpredictable consequences for the upcoming winter tourist season. In the first year of the coronavirus's existence, serious damage is caused to the tourism business and consumers' perceptions of safe travel. However, the social and economic impact of the spread of the coronavirus pandemic has yet to be analyzed and assessed in order to limit the negative impacts of subsequent health crises on this industry.

\section{REFERENCES}

[1] Ministry of tourism, https://www.tourism.government.bg/ bg/kategorii/novini/ministur-angelkova-na-rabotna-sreshta-vbryuksel-s-evrokomisarya-po-transport-adina

[2] National Tourist Information Center, https://bulgariatravel.org/wpcontent/uploads/2016/publication_5870_1.pdf [accessed Nov 14 2020].

[3] M. Penerliev, and V. Petkov, "COVID - 19: Initial Geographical Analysis”, SocioBrains, 2020, issue 68, pp. 55-66.

[4] N. Naumov, D. Varadzhakova, and A. Naydenov, "Sanitation and hygiene as factors for choosing a place to stay: perceptions of the Bulgarian tourists", Anatolia, 2020. DOI: 10.1080/13032917.2020.1771742

[5] J. Li, Th. Hong Hai, and J. Nguyen, "Andres Coca-Stefaniak, Coronavirus impacts on post-pandemic planned travel behaviours", Annals of Tourism Research, 2020, 102964, https://doi.org/10.1016/j.annals.2020.102964

[6] H. Han, A. Al-Ansi, B.-L. Chua, B. Tariq, A. Radic, and S.-H. Park, "The Post-Coronavirus World in the International Tourism Industry: Application of the Theory of Planned Behavior to Safer Destination Choices in the Case of US Outbound Tourism", Int. J. Environ. Res. Public Health, 2020, no 17, p. 6485

[7] S.S. Wachyuni, and D.A. Kusumaningrum, "The Effect of COVID-19 Pandemic: How are the Future Tourist Behavior?", Journal of Education, Society and Behavioral Science, 2020, no 33(4), pp. 67-76

[8] M. Ivanova, I. Krasimirov Ivanov, and S. Ivanov, "Travel behaviour after the pandemic: the case of Bulgaria", Anatolia, 2020. DOI: 10.1080/13032917.2020.1818267

[9] S.R. Ramya, and M. R. Vanithamani, "Public Perception Towards Post COVID tourism", Journal of Technology, 2020, no 35(3), pp. 192-196. https://www.researchgate.net/publication/344708100_PUBLIC_PER CEPTION_TOWARDS_POST_COVID_TOURISM

[10] M. Özdemir, and E. Ergun, "Pandemic and Post Pandemic Process from Perspective of Incoming Travel Agencies", Conference: Atlas International Congress on Social Sciences, 2020, no 7.

[11] T. Ayad et al., "The future of tourism post COVID-19 pandemic: from theegyptian tour operators perspectives", JAAUTH, 2020, Vol. 18, No. 3, pp. 50-64.

[12] S. Praveenkumar, "Impact and Recovering Strategies for Tourism and Hotel Industry Post COVID-19 in INDIA", Dogo Rangsang Research Journal UGC Care Group I Journal, 2020, Vol-10, Issue-09 No. 02, p. 80

https://www.researchgate.net/publication/344176702_IMPACT_AND _RECOVERING_STRATERGIES_FOR_TOURISM_AND_HOTEL INDUSTRY-POST COVID-19 IN INDIA [accessed Nov 11 2020].

[13] N.G. Uğur, and A. Akbıyık, "Impacts of COVID-19 on global tourism industry: A cross-regional comparison", Tourism Management

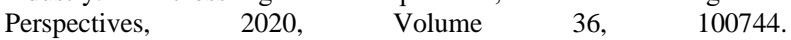
https://doi.org/10.1016/j.tmp.2020.100744.

[14] G. Parady, A. Taniguchi, and K. Takami, "Travel Behavior Changes During the COVID-19 Pandemic in Japan: Analyzing the Effects of Risk Perception and Social Influence on Going-out Self-restriction", Transportation Research Interdisciplinary Perspectives, 2020, Volume 7, 100181. https://doi.org/10.1016/j.trip.2020.100181

[15] Eurostat, https://ec.europa.eu/eurostat/web/nuts/background, accessed on 11 November 2020.

[16] Sofia Investment Agency, https://investsofia.com/wpcontent/uploads/2019/10/Sofia-Tourism-and-Air-Transport-MarketReport-2019-BG.pdf, accessed on 10 November 2020

[17] Sofia airport passenger statistics, https://www.sofiaairport.bg/sites/default/files/bg-passengers_2019-2020_8.pdf, accessed on 10 November 2020. 